\title{
Evaluation of the chemical and thermo-physical properties of locally aggregated kaolin-based refractory materials
}

\author{
A. A. Olalere, S. S. Yaru and O. A. Dahunsi* \\ Mechanical Engineering Department, Federal University of Technology, Akure, Ondo \\ State, NIGERIA \\ Phone: +2348162539990 \\ *Email: oadahunsi@futa.edu.ng, tundedahunsi@gmail.com
}

\begin{abstract}
There is a continuous demand for refractory materials to meet the increasing expansion of industries and plants. Local clay materials are being explored to augment the inadequate supply of refractory materials. This study therefore evaluated the suitability of locally aggregated kaolin as refractory material. The kaolin was aggregated from Ipinsa kaolin, termite hill materials and bentonite in the ratio 5:4:1 by mass. Chemical analysis carried out on the materials using Proton Induced X-ray Emission (PIXE) Equipment revealed that the kaolin aggregate had a composition of $37.22 \%$ alumina $\left(\mathrm{Al}_{2} \mathrm{O}_{3}\right)$ and $51.93 \%$ silica $\left(\mathrm{SiO}_{2}\right)$. The Ipinsa kaolin comprised $\mathrm{Al}_{2} \mathrm{O}_{3}$ at $43.05 \%$ and $\mathrm{SiO}_{2} 53.91 \%$, termite hill material $\left(\mathrm{Al}_{2} \mathrm{O}_{3}\right.$ $22.69 \%, \mathrm{SiO}_{2} 58.83 \%$ ) and bentonite had $23.10 \% \mathrm{Al}_{2} \mathrm{O}_{3}$ and $55.40 \% \mathrm{SiO}_{2}$. It shows that Ipinsa kaolin can be used for refractory materials in furnaces, kilns and stoves while the aggregated clay can be used in applications requiring more superior refractory properties. The thermo-physical analysis of the aggregated clay revealed a bulk density of $1.84 \mathrm{~g} / \mathrm{cm}^{3}$, apparent porosity $31.54 \%$, linear shrinkage $4.00 \%$, thermal shock resistance $40^{+}$and refactoriness $1900{ }^{\circ} \mathrm{C}$. The refractoriness indicated that the aggregated clay is also suitable for use as ceramic fibre within the temperature range of 1800 and $2000{ }^{\circ} \mathrm{C}$.
\end{abstract}

Keywords: Evaluation; chemical; PIXE; kaolin; termite

\section{INTRODUCTION}

Refractory clay minerals are part of the numerous natural resources in abundant supply in Nigeria. There is also a growing prospect for production of refractory clay bricks for companies and industries that deal in manufacturing of high operating temperature equipments such as furnace, boiler, oven and kiln. Metallurgical industries such as those for iron and steel consume about $70 \%$ of such refractory products [1]. Demand for refractory products in the non-metallurgical industries like the chemical, glass, boiler and petrochemical industries stand at about 20-30\% [2] but the refractory needs of these industries rose to 300,000 tonnes at the end of the year 2000 [3].

Application of clay minerals in various engineering, petroleum and manufacturing industries are closely related to their structure and composition. The important characteristics associated with commercial application of clay minerals are particle size, surface chemistry, 
particle shape, surface area, and other physical and chemical properties specific to a particular application such as viscosity, colour, plasticity, green strength, dry and fired strength, absorption and adsorption, abrasion and others [4].

According to Yami and Umar [5] refractories of various types can be produced from kaolinite $\left(\mathrm{Al}_{2} \mathrm{O}_{3} .2 \mathrm{SiO}_{2} .2 \mathrm{H}_{2} \mathrm{O}\right)$, chromite $\left(\mathrm{FeOCr}_{2} \mathrm{O}_{3}\right)$ and magnesite $\left(\mathrm{MgCO}_{3}\right)$, and these materials can be obtained from many clay types. Additives like sawdust, groundnuts shell, palm kennel shell, silica sand and binders are added to the clays improve the quality of refractories products and these materials can all be sourced locally.

Formation of kaolin may be through hydrothermal and volcanic clay deposits or by means of residual and sedimentary clay deposits [6]. In the last few years, there have been tremendous works in developing refractory products from local clay deposits and it has been found that local refractory clays are suitable for use in furnace lining and steel industries [5]. The characteristics of some Otukpo clays were studied [7]. They found that the clays had refractoriness of about $1710{ }^{\circ} \mathrm{C}$ and this compared favourably with the refractoriness of the usually imported refractory materials.

Refractory materials used for insulating purposes have high porosity with low thermal conductivity and high thermal insulation properties appropriate for minimizing heat losses and maximizing heat conservation in furnaces. Their low thermal conductivities are as a result of the pores and their heat capacity is determined nearly completely by their solid component. The alumina-silicate clay with high porosity has high insulating properties and low thermal conductivity [8]. Table 1 outlines some thermal and physical properties of clay materials evaluated from different locations within the country in the literature. Table 2 shows the chemical composition of several kaolin based clay materials from different locations in Nigeria.

Table 1. Summary of thermo-physical properties of some Nigerian kaolin

\begin{tabular}{|c|c|c|c|c|c|c|c|}
\hline $\begin{array}{l}\text { RESEARCHER } \\
\text { NAME }\end{array}$ & $\begin{array}{l}\text { SAMPLE } \\
\text { LOCATION }\end{array}$ & $\begin{array}{c}\text { BULK } \\
\text { DENSITY } \\
\left(\mathrm{g} / \mathrm{cm}^{\mathbf{3}}\right)\end{array}$ & $\begin{array}{c}\text { APPARENT } \\
\text { POROSITY } \\
(\%)\end{array}$ & PERMEABILITY & $\begin{array}{l}\text { LINEAR } \\
\text { SHRINKAGE } \\
(\mathbf{m m})\end{array}$ & $\begin{array}{c}\text { THERMAL } \\
\text { SHOCK } \\
\text { RESISTANCE } \\
\text { (Cycle) } \\
\end{array}$ & $\begin{array}{c}\text { REFRACTORIENESS } \\
\left({ }^{\circ} \mathrm{c}\right)\end{array}$ \\
\hline \multirow{4}{*}{$\begin{array}{l}\text { Titiladunayo and } \\
\text { Fapetu [9] }\end{array}$} & Ikere & 1.7400 & 31.4400 & - & 5.0000 & - & 1500.0000 \\
\hline & Fagbohun & 2.0000 & 20.6900 & - & 2.0000 & - & 1500.0000 \\
\hline & Ishan & 2.0000 & 19.1000 & - & 1.5000 & - & 1300.0000 \\
\hline & Ara & 1.9900 & 23.3100 & - & 1.9000 & - & 1300.0000 \\
\hline \multirow{2}{*}{$\begin{array}{l}\text { Yami and Umar } \\
\text { [5] }\end{array}$} & Gur & 2.1100 & 19.5000 & 215.0000 & 1.1100 & 7.0000 & 1370.0000 \\
\hline & Yamarkumi & 2.0600 & 22.2600 & 489.0000 & 1.0000 & 5.0000 & 1400.0000 \\
\hline \multirow[t]{3}{*}{ Ogunniyi [10] } & Ijapo & 1.3800 & 50.1500 & - & - & - & - \\
\hline & Igbokoda & 1.7700 & 28.1800 & - & - & - & - \\
\hline & Onibode & 2.6000 & 28.4000 & 87.0000 & 4.0000 & 30.0000 & 1760.0000 \\
\hline \multirow{6}{*}{$\begin{array}{l}\text { Borode et. al. } \\
\text { [11] }\end{array}$} & Ara-Ekiti & 1.8400 & 18.0000 & 75.0000 & 8.0000 & 26.0000 & 1650.0000 \\
\hline & Ibamojo & 1.7600 & 16.0000 & 78.0000 & 4.0000 & 30.0000 & 1630.0000 \\
\hline & Ijoko & 2.6000 & 22.0000 & 88.0000 & 6.0000 & 28.0000 & 1680.0000 \\
\hline & Ikere- Ekiti & - & 43.1000 & - & 3.5900 & 20.0000 & 1450.0000 \\
\hline & Isan & - & 49.7000 & - & 3.8900 & 32.0000 & 1520.0000 \\
\hline & $\begin{array}{l}\text { Ezinachi- } \\
\text { Okigwe }\end{array}$ & - & 20.0000 & - & 7.2300 & 20.0000 & 1350.0000 \\
\hline \multirow[t]{4}{*}{ Okoli [12] } & Onibode & - & 23.0000 & Moderate & - & Fair & High \\
\hline & Ozubulu & - & 25.0000 & Moderate & - & Fair & High \\
\hline & Kankara & - & 18.0000 & Low & - & Fair & High \\
\hline & SabonGida & - & 20.0000 & Low & - & - & High \\
\hline
\end{tabular}


Table 2. Summary of Chemical Properties of Some Nigerian Kaolin Materials

\begin{tabular}{|c|c|c|c|c|c|c|c|c|c|c|}
\hline $\begin{array}{l}\text { NAME OF THE } \\
\text { RESEARCHER }\end{array}$ & LOCATION & YEAR & $\begin{array}{c}\mathbf{A L}_{2} \mathbf{O}_{3} \\
(\%)\end{array}$ & $\mathrm{SIO}_{2}(\%)$ & $\begin{array}{c}\mathbf{K}_{2} \mathbf{O} \\
(\%)\end{array}$ & $\begin{array}{c}\text { CAO } \\
(\%)\end{array}$ & $\begin{array}{c}\mathbf{T I}_{2} \mathbf{O} \\
(\%)\end{array}$ & $\begin{array}{c}\text { MNO } \\
(\%)\end{array}$ & $\begin{array}{c}\mathrm{FE}_{2} \mathbf{O}_{3} \\
(\%)\end{array}$ & OTHERS \\
\hline \multirow[t]{5}{*}{ Folorunso et. al. [13] } & Ifon & 2014 & 22.420 & 63.3500 & 2.8780 & 0.6890 & 0.9230 & 0.1117 & 6.1090 & 3.5193 \\
\hline & Igbara Odo & & 25.737 & 56.6360 & 2.9400 & 0.9110 & 0.8950 & - & 9.2260 & 3.6550 \\
\hline & Ipetumodu & & 25.030 & 59.4820 & 1.2590 & 0.7630 & 1.5120 & 0.0450 & 8.6520 & 3.2570 \\
\hline & Ihan & & 23.980 & 54.6570 & 2.5130 & 0.8430 & 1.5770 & 0.1090 & 10.4080 & 5.9130 \\
\hline & Iseyin & & 22.729 & 62.2920 & 1.3600 & 0.5410 & 1.0460 & 0.0500 & 7.2660 & 4.7160 \\
\hline \multirow[t]{3}{*}{ Manukaji [14] } & Uhodo & 2013 & 35.000 & 44.0000 & 1.5000 & 0.5000 & 2.4000 & - & 1.3000 & 15.3000 \\
\hline & Oguma & & 34.000 & 45.0000 & 1.4000 & 0.4000 & 1.5000 & - & 1.5000 & 16.2000 \\
\hline & Odoji & & 34.000 & 46.0000 & 1.2000 & 0.2000 & 3.0000 & - & 0.9000 & 14.7000 \\
\hline Akinlabi, e.t al. [15] & Ijero & 2013 & 39.600 & 58.0000 & 0.8950 & - & 0.0200 & 0.0510 & 0.6380 & 0.7960 \\
\hline \multirow{4}{*}{$\begin{array}{l}\text { Titiladunayo and } \\
\text { Fapetu [9] }\end{array}$} & Ikere & 2011 & 30.460 & 50.9200 & 0.3300 & 0.1900 & 1.7800 & 0.0100 & 2.0700 & 14.2400 \\
\hline & Fagbohun & & 18.750 & 53.9000 & 3.3000 & 0.7200 & 2.2900 & 0.0300 & 11.8000 & 9.2100 \\
\hline & Ishan & & 13.480 & 40.6800 & 2.8800 & 1.1200 & 2.6800 & 0.1500 & 25.5500 & 13.4600 \\
\hline & Ara & & 10.920 & 59.9000 & 3.2500 & 1.9000 & 2.7600 & 0.1900 & 11.4000 & 9.6800 \\
\hline \multirow[t]{2}{*}{ Yami and Umar [5] } & Gur & 2007 & 21.250 & 59.2000 & - & 1.9200 & - & - & 15.7000 & 1.9300 \\
\hline & Yamarkumi & & 19.680 & 41.8000 & - & 1.5200 & - & - & 8.8900 & 28.1100 \\
\hline \multirow[t]{2}{*}{ Ogunniyi [10] } & Ijapo & 2003 & 28.830 & 52.2000 & - & - & - & - & 3.5800 & 15.3900 \\
\hline & Igbokoda & & 1.1300 & 92.5400 & - & - & - & - & 1.1900 & 5.1400 \\
\hline \multirow[t]{3}{*}{ Ijagbemi [16] } & Ikeji- Arakeji & 2002 & 19.690 & 48.2400 & 3.0000 & 0.5500 & 1.5100 & - & 10.8100 & 16.2000 \\
\hline & Ibule & & 19.250 & 56.0900 & 7.2100 & 0.3200 & 1.4800 & - & 7.2100 & 8.4400 \\
\hline & Ikere & & 30.820 & 47.1400 & 2.5300 & 0.2500 & 0.5000 & - & 2.0000 & 16.76 \\
\hline \multirow[t]{8}{*}{ Borode et. al. [11] } & Onibode & 2000 & 36.600 & 46.1000 & 1.2000 & 0.1400 & 1.3200 & - & 0.7600 & 13.8800 \\
\hline & Ara & & 28.600 & 56.6600 & 0.0800 & 0.1500 & 1.8800 & - & 1.4700 & 11.1600 \\
\hline & Ibamojo & & 22.800 & 54.4400 & 1.0000 & 0.3000 & 0.8600 & - & 1.0000 & 19.6000 \\
\hline & Ijoko & & 37.240 & 47.1100 & 0.0400 & 0.0700 & 0.9200 & - & 0.5600 & 14.0600 \\
\hline & Ijapa & & 30.790 & 47.5010 & 1.9170 & 4.7700 & - & - & 0.4910 & 14.5310 \\
\hline & Ikere & & 31.460 & 47.3800 & 0.2962 & 0.0237 & 1.1380 & - & 9.8700 & 9.8321 \\
\hline & Ishan & & 19.510 & 51.1000 & 2.5290 & 0.3296 & 1.4840 & - & 9.8200 & 15.2274 \\
\hline & $\begin{array}{l}\text { Ezinachi- } \\
\text { Okigwe }\end{array}$ & & 34.730 & 45.0000 & 0.1400 & Traces & 4.0200 & - & 1.2700 & 14.8400 \\
\hline \multirow[t]{4}{*}{ Okoli [12] } & Onibode & 2000 & 39.300 & 42.3000 & - & - & - & - & Trace & 18.4000 \\
\hline & Ozubulu & & 19.310 & 58.3000 & - & - & - & - & 1.5500 & 20.8400 \\
\hline & Kankara & & 38.640 & 44.5000 & - & - & - & - & Nil & 16.8600 \\
\hline & Sabon-Gida & & 25.880 & 25.3200 & - & - & - & - & 13.1000 & 35.7000 \\
\hline \multirow{8}{*}{$\begin{array}{l}\text { Delta Steel Company } \\
\text { ltd.,Aladja [17] }\end{array}$} & Nsu & 1984 & 30.220 & 50.6000 & - & - & - & - & 1.9000 & 17.2800 \\
\hline & Ukpor & & 33.200 & 48.0000 & - & - & - & - & 1.2000 & 17.6000 \\
\hline & Ozubulu & & 19.310 & 58.3000 & - & - & - & - & 1.5500 & 20.8400 \\
\hline & Enugu & & 22.710 & 55.0000 & - & - & - & - & 2.3200 & 19.9700 \\
\hline & Onibode & & 39.300 & 42.3000 & - & - & - & - & Traces & 18.4000 \\
\hline & Orun & & 34.550 & 50.5000 & - & - & - & - & 2.0500 & 12.9000 \\
\hline & Oshiele & & 28.300 & 53.4000 & - & - & - & - & 1.3500 & 16.9500 \\
\hline & Werromi I & & 36.120 & 45.1600 & - & - & - & - & 2.3000 & 16.4200 \\
\hline
\end{tabular}




\begin{tabular}{|c|c|c|c|c|c|c|c|c|}
\hline Werrom II & 38.140 & 41.9200 & - & - & - & - & - & 19.9400 \\
\hline Alkaleri & 25.430 & 54.5000 & - & - & - & - & 1.0500 & 19.0200 \\
\hline Kankara & 38.670 & 44.5000 & - & - & - & - & - & 16.8300 \\
\hline Giro & 38.720 & 41.2600 & - & - & - & - & 2.1000 & 17.9200 \\
\hline Sabon Gida & 25.580 & 25.3200 & - & - & - & - & 13.1000 & 36.0000 \\
\hline Ifon & 36.800 & 47.9000 & - & - & - & - & 0.6700 & 14.6300 \\
\hline Okpekpe & 24.300 & 53.2000 & - & - & - & - & 1.4500 & 21.0500 \\
\hline
\end{tabular}

Porous firebricks were produced from the mixture of clay with $10 \%, 20 \%$ and $30 \%$ recycled refractory wastes of expanded perlite [18]. The authors reported that the mixture containing 30\% expanded perlite was the best as it had porosity of $65.8 \%$ as against $51.5 \%$ and $57.5 \%$ for the mixtures with $10 \%$ and $20 \%$ perlite respectively. The performance evaluation of refractory bricks of clay samples from Oghara, Ekpan, Ubeji and Jeddo communities were carried out in Delta State [19]. It was reported that the Oghara clay was the best among the four samples. It can therefore be used for wall lining material in high temperature equipment of Warri Refining and Petrochemical Company with temperature below $1200{ }^{\circ} \mathrm{C}$. Clay samples from Nafuta in Barkin Ladi area of Plateau State, Nigeria were investigated for refractory bricks application [20]. The report was that the bricks had refractoriness of $1600{ }^{\circ} \mathrm{C}$ with low concentration of iron II oxide $\left(\mathrm{Fe}_{2} \mathrm{O}_{3}\right)$ and they could be used as lining materials in furnaces, kilns, incinerators and reactors.

Clay material obtained from a single site cannot however possess all the required properties that will make it a perfect refractory material, hence the need to select clays based on their physical, chemical and thermal analyses. The selected refractory material will have to be beneficiated with refractory clay materials from other sites and properly blended with other additives to improve its properties [21]. For instance, the effect of Portland cement on the refractory properties of clay samples from Awo and Ipetumodu in Oyo State, Nigeria was investigated [22]. They reported that the thermal shock resistance of the clays increased when they were blended with $20 \%$ to $30 \%$ cement. The mechanical properties of Ifon clay from Ondo State were improved by bonding it with spent graphite electrode [23]. Studies on the refractory properties of the mixture of Uwana beach silica sand, Ekebedi and Unwana clay samples were carried out and it was reported that Unwana beach sand was most suitable for the manufacture of aluminosilicate refractory brick [24]. The characterization of Dabagi clay sample from Gwandu, Kebbi State was carried out and the authors reported that its apparent porosity of $28.46 \%$ made it suitable for use as refractory brick, fireclay, siliceous fireclay and ceramics [25]. Three clay soils from Abaji were investigated for refractory applications [26]. They found out that the clays were alumina-silicate clays as they respectively had $49.98 \%$, $36.89 \%$ and $44.38 \%$ silica while the alumina contents in the same order were $16.39 \%$, $20.12 \%$ and $18.33 \%$. These clay samples were found suitable for furnace and heat treatment lining materials as each of them recorded refractoriness of $1100{ }^{\circ} \mathrm{C}$. Studies was done on bricks made of charmotte obtained from calcinations of clay in Apata Ile Ife, Osun State mixed with potter's clays. The composition of the charmotte in the mixture was separately at $100 \%, 80 \%, 60 \%, 40 \%$, and $20 \%$ [27]. They reported that the brick with $80 \%$ charmotte content and 20\% raw kaolin recorded the highest thermal shock resistance. The thermal shock resistances and cold crushing strength of the bricks also increased with increase in the charmotte content in the mixture. 
Refractory materials used especially for insulating purpose can also be produced from termite hill materials. Termite hill material mixed with $25 \%$ additives from corn husk and sawdust was used to produce insulating refractory material [28]. Low values of refractoriness $\left(1200{ }^{\circ} \mathrm{C}\right)$ were recorded but the property improved through the addition of kaolin, and bentonite to attain the refractoriness of $1500{ }^{\circ} \mathrm{C}$. The refractory properties of termite hill materials made it suitable for furnace lining [29]. Anthill clay from Cheptebo in rift valley, Kenya was investigated for the production of refractory materials [30]. The authors reported that the anthill clay was siliceous in nature and it was of the alumina-silicate family. This clay could be used for the manufacture of alumina-silicate fibre glass.

The objective of this paper therefore is to evaluate the chemical and thermo-physical properties of the aggregate formed from mixing together kaolin obtained in Ipinsa, termite hill materials and bentonite for refractory materials.

\section{MATERIALS AND METHODS}

During the process of material collection and preparation, five representative clay samples were collected from five different locations from a kaolin deposit at Ipinsa near the Federal University of Technology, Akure (FUTA) North Gate along Ilesha-Benin express way, Akure, Ondo State, Nigeria. Akure is located within the humid south western region of Nigeria on latitude $7^{\circ} 16^{\prime} \mathrm{N}$; longitude $5^{\circ} 13^{\prime} \mathrm{E}$.

The clay samples were properly blended together to have a very good representation of the kaolin deposit from the sites. The distance between the points in the field at which the clay samples were collected was $150 \mathrm{~m}$. Termite hill materials was extracted from a termite hill within FUTA. Processed bentonite was purchased at Pascal Scientific Limited, Alagbaka, Akure and was mixed such that $50 \mathrm{~kg}$ of the Ipinsa clay material was mixed with $40 \mathrm{~kg}$ termite hill material and $10 \mathrm{~kg}$ of the processed bentonite to attain a ratio 5:4:1. The samples were crushed into powdery form using small porcelain mortar and pestle. They were then made into pellets of about $500 \mathrm{mg}$ and $13 \mathrm{~mm}$ diameter using pellets making set, being the method used by [31, 32].

\section{Proton Induced X-ray Emission Analysis}

The elemental properties of the refractory materials was then analysed with the Proton Induced X-ray Emission (PIXE) equipment at the Centre for Energy Research and Development (CERD) at Obafemi Awolowo University, Ile- Ife, Nigeria. PIXE analysis use proton beams produced by Ion Beam Analysis (IBA) facility of $1.7 \mathrm{MeV}$ Tandem Accelerators. The PIXE system was calibrated using the National Institute of Standards and Technology (NIST) and geological standard 278B_PIX_K8 was used for quality assurance and control of results.

The IBA facility used for this analysis consists of a 5SDH modelled NEC Tandem Pelletron accelerator complete with an end station made up of Aluminum chamber $150 \mathrm{~cm}$ diameter and height $180 \mathrm{~cm}$. The samples were irradiated by a $4 \mathrm{~mm}$ diameter beam of protons with energy of $2.5 \mathrm{MeV}$ and beam current of $0.2 \mathrm{nA}$ for 900 seconds.

The chamber of the accelerator had four ports and a window. The second port, inclined at $135^{\circ}$ to the horizontal, is used for PIXE detector. This detector is an ESL X 30150 model of a Cambera $\mathrm{Si}(\mathrm{Li})$ detector with resolution $175 \mathrm{eV}$ at $5.9 \mathrm{Kev}$ which is coupled 
to a Canberra Inspector 2000 Digital Signal Processor. Canberra Ganie-3.1 software was used for acquisition of the PIXE data [33-35].

Gupxwin computer code was used for fitting the experimentally generated PIXE spectrum prior to quantitative analysis [36]. A filter placed between the detector and the samples cut off unwanted signal frequencies. The physical and thermal properties were determined using the principle employed by $[5,32,37]$

\section{Bulk Density and Apparent Porosity}

These properties were determined in accordance with standard test procedures in BS 1902 part 1A [38].The aggregate mixture of the Ipinsa kaolin, termite hill materials and bentonite was mixed with water until it plastically formed. The sample was then moulded into shapes of $6 \mathrm{~cm} \times 6 \mathrm{~cm} \times 1.5 \mathrm{~cm}$ and they were air dried for 24 hours. They were also put into a muffle furnace and dried at $110{ }^{\circ} \mathrm{C}$ for another 24 hours before they were fired to $1200{ }^{\circ} \mathrm{C}$ for 30 minutes. They were thereafter allowed to cool in the desicators for 24 hours. These specimens were used in the determination of their bulk density and apparent porosity.

The test samples, after they were fired to $1200{ }^{\circ} \mathrm{C}$ and cooled, were weighed and recorded as $\mathrm{W}_{1}$. The specimens were attached to an inextensible string from which they were suspended, transferred and immersed into a beaker of water and heated for 30 minutes to assist in bobbling the trapped air in the specimen. The pores in the specimen were then filled with water. The weights of the specimen were now recorded $W_{2}$. The specimens were thereafter suspended in a beaker containing water placed on a balance. The suspended weight $\left(W_{3}\right)$ was taken and the bulk density was calculated from equation (1).

$$
\text { Bulk density }=\frac{W_{1}}{W_{2}-W_{3}}
$$

Apparent porosity is determined using equation (2).

$$
\text { Apparent porosity }=\frac{\left(W_{2}-W_{1}\right)}{\left(W_{2}-W_{3}\right)} * 100 \%
$$

\section{Thermal Shock Resistance}

The samples upon preparation were dried at room temperature for 12 hours before they were put into an oven to dry at $110{ }^{\circ} \mathrm{C}$ for 24 hours. They were thereafter transferred to a muffle furnace now set at $1200{ }^{\circ} \mathrm{C}$ and the specimens were allowed residence there for 30 minutes. They were removed from the furnace to be cooled for 20 minutes and were put back to the furnace for another 20 minutes. The procedure was continued till the test pieces fractured. The alternate heating and cooling before the test pieces fractured determined the number of cycles they went through and this was the value of the thermal shock resistance [39].

\section{Linear Shrinkage}

The test pieces were made in rectangular form of $10 \mathrm{~cm} \times 3 \mathrm{~cm} \times 3 \mathrm{~cm}$ and a $6 \mathrm{~cm}$ line was marked along its length so as to keep the same spot after heat treatment. The length of the line on the specimen was measured with a vernier calliper. The samples were dried at room 
temperature for 24 hours before they were transferred to the oven to dry further at $110{ }^{\circ} \mathrm{C}$ for another 24 hours. They were then fired up to $1200^{\circ} \mathrm{C}$ for 6 hours. The test pieces were cooled to room temperature and measurements of the marked line was taken again. The fired specimen linear shrinkage was calculated using equation (3). This method was employed in the ASTM 15.02; C326 method [40].

$$
\text { Linear shrinkage }=\frac{\left(L_{1}-L_{2}\right)}{L_{1}} * 100 \%
$$

where, $L_{1}$ is the length of the line on the unfired test specimen; and $L_{2}$ is the length of the same line on the fired specimen

\section{Refractoriness}

This is the temperature at which a refractory bends as it can no longer support its weight as it is exposed to high temperature [41]. The test samples were first dried at room temperature before being mounted on a refractory plague together with a standard cone with a melting point slightly lower than the melting point expected of the test cone. The set up was then put inside the muffle furnace and its temperature was raised at a rate of $100{ }^{\circ} \mathrm{C}$ per minute. The test continued until the tip of the test cone bent over the level with the base. The plague with the test piece on it was removed and cooled at room temperature. The test cone was examined with the microscope. The test was similar to those in ASTM 15.01; CO8.02 [42].

\section{RESULTS AND DISCUSSION}

The PIXE chemical analysis of the Ipinsa clay sample, termite hill materials, bentonite and that of their mixture aggregated at 5:4:1 by mass is shown in Table 4 while the spectral distribution of this PIXE analysis is shown in Figure 1.

Table 3. Elemental composition of ipinsa clay, termite hill materials, bentonite and the aggregated mixture.

\begin{tabular}{|c|c|c|c|c|}
\hline \multirow[b]{2}{*}{ Elemental Composition (\%) } & \multicolumn{4}{|c|}{ Refractory Materials Samples } \\
\hline & $\begin{array}{l}\text { Ipinsa } \\
\text { Kaolin }\end{array}$ & $\begin{array}{c}\text { Termite Hill } \\
\text { Material }\end{array}$ & Bentonite & $\begin{array}{c}\text { Aggregate } \\
\text { Used }\end{array}$ \\
\hline Alumina $\left(\mathrm{Al}_{2} \mathrm{O}_{3}\right)$ & 43.05 & 22.69 & 23.10 & 37.22 \\
\hline Silica $\left(\mathrm{SiO}_{2}\right)$ & 53.91 & 58.83 & 55.40 & 51.93 \\
\hline Magnesium oxide $(\mathrm{MgO})$ & 0.26 & 0.84 & 2.50 & 0.71 \\
\hline Iron III oxide $\left(\mathrm{Fe}_{2} \mathrm{O}_{3}\right)$ & 1.72 & 2.42 & 4.40 & 8.08 \\
\hline Calcium oxide $(\mathrm{CaO})$ & 0.03 & 0.01 & 0.20 & 0.12 \\
\hline Titanium oxide $\left(\mathrm{TiO}_{2}\right)$ & 0.12 & 0.72 & - & 0.86 \\
\hline Manganese oxide $(\mathrm{MnO})$ & - & - & 0.02 & 0.05 \\
\hline Strontium oxide $(\mathrm{SrO})$ & - & - & - & 0.01 \\
\hline Zirconia $\left(\mathrm{ZrO}_{2}\right)$ & 0.03 & - & - & 0.09 \\
\hline Potassium oxide $\left(\mathrm{K}_{2} \mathrm{O}\right)$ & 0.88 & 2.10 & 3.00 & 0.90 \\
\hline Zinc oxide $(\mathrm{ZnO})$ & - & - & - & 0.02 \\
\hline Rubidium oxide (RbO) & 0.01 & - & - & - \\
\hline
\end{tabular}




\begin{tabular}{ccccc} 
Sodium oxide $\left(\mathrm{Na}_{2} \mathrm{O}\right)$ & - & 0.06 & 3.00 & - \\
Others & - & - & 0.58 & - \\
\hline
\end{tabular}

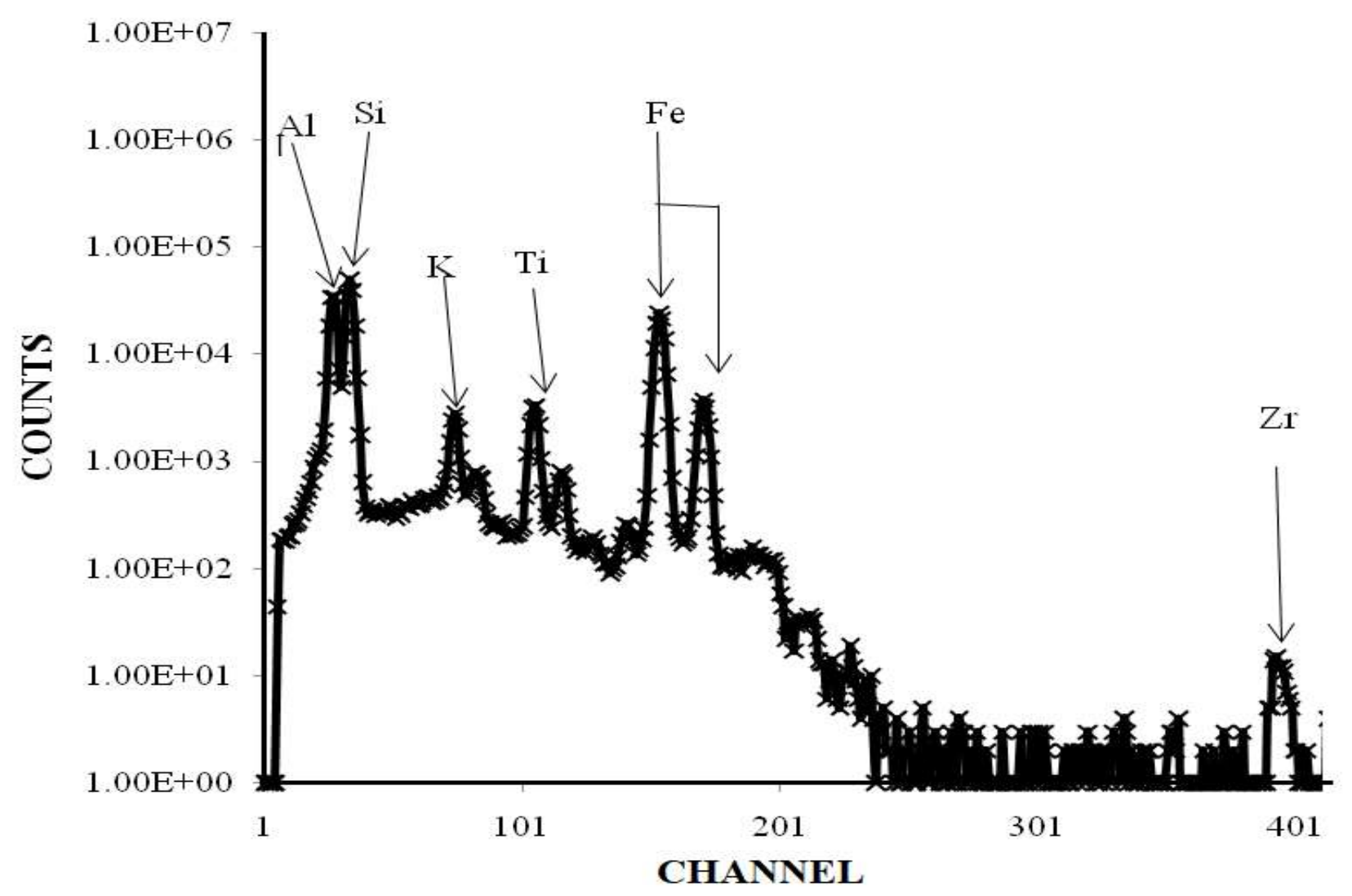

Figure 1. Proton induced x-ray emission (PIXE) analysis spectrum of the refractory materials.

As shown in Table 4, the alumina $\left(\mathrm{Al}_{2} \mathrm{O}_{3}\right)$ content $(43.05 \%)$ and that of silica $\left(\mathrm{SiO}_{2}\right)(53.91 \%)$ make the Ipinsa kaolin suitable for ceramic fibre materials for temperatures up to $1150{ }^{\circ} \mathrm{C}$ [31].The $\mathrm{Al}_{2} \mathrm{O}_{3}$ of termite hill materials (22.69\%), for bentonite (23.10\%) and that of the aggregate obtained from the combination of Ipinsa clay, termite hill materials and bentonite at ratio $5: 4: 1$ by mass $(37.22 \%)$ can therefore be used as refractory materials [7]. The percentage composition of alumina of all the samples conformed to major refractory clays in Nigeria with alumina content less than $45 \%$ [43].

The iron oxide contents of all the samples were high and met the requirement for both refractory and high melting clays. The high iron oxide of the Ipinsa kaolin aggregate of 8.08\% perfectly supports the reddish colour when fired to $1200{ }^{\circ} \mathrm{C}$. This makes it attractive as a ceramic raw material [44]. The high temperature characteristics of the fired bricks make the clay suitable for structural engineering works [7]. 
The amount of titanium oxide $\left(\mathrm{TiO}_{2}\right)$ in Ipinsa kaolin, termite hill materials and the aggregate are less than 1-4\% recommended for refractory clays [45]. Rubidium oxide ( $\mathrm{RbO})$ was only visible in the Ipinsa kaolin with $0.01 \%$, while zinc oxide $(\mathrm{ZnO})$ was only present in the kaolin aggregate with $0.02 \%$. Magnesium oxide $(\mathrm{MgO})$ was detected in all the samples with the highest being found in bentonite which was $2.5 \%$, termite hill material with $0.84 \%$, and then kaolin aggregate with $0.71 \%$ while Ipinsa kaolin had the least with $0.26 \%$ but its fusion temperature is $2800{ }^{\circ} \mathrm{C}$ which is beyond all the melting temperature for non-ferrous metals.

The percentage of calcium oxide $(\mathrm{CaO})$ with a fusion temperature of $2570{ }^{\circ} \mathrm{C}$ in bentonite, kaolin aggregate Ipinsa kaolin and termite hill material is also beyond the melting temperature of the non-ferrous metals. The sum of these oxides were less than $6 \%$ recommended for the total flux sodium oxide $\left(\mathrm{Na}_{2} \mathrm{O}\right)$, potassium oxide $\left(\mathrm{K}_{2} \mathrm{O}\right)$, calcium oxide $(\mathrm{CaO})$ and magnesium oxide $(\mathrm{MgO})$ for refractory clays [45]. Large amount of the oxides facilitates the formation of their liquid-phase at low temperature.

Manganese oxide $(\mathrm{MnO})$ has the highest value in the kaolin aggregate $(0.05 \%)$ composition while that of bentonite was $(0.02 \%)$. With a fusion temperature of $1780{ }^{\circ} \mathrm{C}$, it is very difficult to disintegrate at the melting temperature of non-ferrous metals. Strontium oxide $(\mathrm{SrO})$ was mainly detected in the kaolin aggregate and the fusion temperature is 2415 ${ }^{\circ} \mathrm{C}$. Zirconia $\left(\mathrm{ZrO}_{2}\right)$ was available in the kaolin aggregate in $0.09 \%$ proportion and in Ipinsa kaolin with $0.03 \%$ and fusion temperature of $2677^{\circ} \mathrm{C}$.

The fusion temperature of observed oxides that are dangerous to both health and the environment are all higher than the melting temperature of the non-ferrous scraps, therefore they are not expected to disintegrate and present health and safety hazard to plants and animals within the environment in which the equipment will be operated. Element like $\mathrm{Zn}$ is essentials for good health and development but they are also dangerous to health and environment when their concentration exceeds some limits [46].

In Figure 1, elements like Aluminium (Al), silicon ( $\mathrm{Si}$ ) and iron (Fe) have higher percentage as they recorded higher counts than those of potassium (K) and titanium (Ti) which are in turn higher than zircon (Zr).

Table 4 shows the thermo-physical analyses conducted on the kaolin aggregate. The bulk density of the aggregated clay was lower than the recommended value of $2.06-2.11$ $\mathrm{g} / \mathrm{cm}^{3}$ for clay samples and $1.90 \mathrm{~g} / \mathrm{cm}^{3}$ for fireclay [47]. This can be improved with the addition of some additives. The apparent porosity (31.54\%) of the aggregated sample falls within the range of 20-30\% recommended values for clays [3]. The linear shrinkage (4.00\%) of the aggregated clay fell within the recommended value of $4-10 \%$ for fireclay while the thermal shock resistance for the clay sample is even higher than the recommended value of 20-30 cycles for fireclay [3]. Refractoriness of the aggregated clay was higher than the value recommended for fireclay [5]. This value of refractoriness could be due to the high percentage of the alumina content after the aggregate kaoline had been fired [29]. The refractoriness of refractory materials is directly proportional to its softening temperature; this is expressed as its Pyrometric Cone Equivalent (PCE) [37]. The PCE that is equivalent to the refractoriness of the aggregate sample is cone number 40 which is equivalent to $1900{ }^{\circ} \mathrm{C}$. This value is higher than the temperature range $1745-1760{ }^{\circ} \mathrm{C}$ for super duty clay which are used in furnaces, kilns and stoves [32]. 
Table 4. Thermo-physical analysis of the aggregated clay

\begin{tabular}{clc}
\hline S/N & Analysis & $\begin{array}{c}\text { Kaolin Aggregate } \\
\text { Used }\end{array}$ \\
\hline 1 & Bulk density $\left(\mathrm{g} / \mathrm{cm}^{3}\right)$ & 1.84 \\
2 & Apparent porosity $(\%)$ & 31.54 \\
3 & Linear shrinkage $(\%)$ & 4.00 \\
4 & Thermal shocks resistance (cycles) & $40+$ \\
5 & Refractoriness $\left({ }^{\circ} \mathrm{C}\right)$ & 1900 \\
\hline
\end{tabular}

\section{CONCLUSION}

In this work, the chemical composition of clay sample from Ipinsa, termite hill material and processed bentonite as well as that for their aggregate at 5:4:1 are presented. The thermo physical properties of the mixture are also evaluated for refractory materials. The study indicated that the Ipinsa clay sample, termite hill material, the bentonite and their aggregate are kaolinitic as each of them contained higher percentage of silica than alumina. The Ipinsa kaolin can be used as refractory materials for furnaces, kilns and stoves. The aggregated clay from Ipinsa kaolin, termite hill materials and bentonite can find application in super duty refractories. The aggregated clay can also be used for ceramic material within the temperature range of 1800 and $2000{ }^{\circ} \mathrm{C}$ based on its pyrometric cone equivalent value of $1900{ }^{\circ} \mathrm{C}$. The thermo-physical properties tested on this clay conformed to the recommended values for fireclay except the bulk density. It is opined that this would improve if some additives and binders are mixed with the clay. This shows that refractory materials from Ipinsa kaolin and the aggregated clay can compete favourably with the foreign refractory materials.

\section{ACKNOWLEDGEMENTS}

The authors wish to thank the Centre for Energy Research and Development (CERD), Obafemi Awolowo University, Ile-Ife, Osun State, which made this investigation possible through the provision of some of the facilities needed. 


\section{REFERENCE}

[1] Garbers-Craig AM. Presidential address: how cool are refractory materials? The Journal of Southern African Institute of Mining and Metallurgy 2008;108(9):1-16.

[2] Aderibigbe A, Chukwuogo, B. Potentials of some Nigerian clay deposits as refractory material for steel industry. In Proceedings of Nigerian Society Engineers 1984;132138.

[3] Omowumi OJ. Characterization of some Nigerian clay as refractory materials for furnace lining. Nigerian Journal of Engineering Management 2001;2(3): 1-4.

[4] Murray HH. Common clay in: Carr dd ed. industrial minerals and rocks. Littleton, Colorado. Society for Mining, Metallurgy and Exploration 1994:247-248.

[5] Yami AM, Umar, S. Characterization of some Nigerian clays as refractory materials for furnace lining. Continental Journal Engineering Sciences 2007;2(3):30-35.

[6] Arogundade BA, Adebimpe RA, Fashuba AO. An investigation into the effects of various additives on the refractory properties of Ara-Ekiti clay. Ekiti state. Journal of Engineering Technology and Industrial Application 2000;1(2):188-194.

[7] Nnuka EE, Agbo UJE. Evaluation of the refractory characteristics of Otukpo clay deposits. Nigerian Society of Engineers Technical Transaction 2000; 35(2):34-41

[8] Iyasara AC, Ekeyem SC, Geofrey O, Benjamin N. Influence of grog size on the performance of Nsu clay-based dense refractory bricks. American Journal of Materials Science and Engineering 2016; 4(1):7-12.

[9] Titiladunayo IF, Fapetu OP. Selection of appropriate clay for furnace lining in a pyroiysis process. Journal of Emerging Trends in Engineering and Applied Science 2011;2(6): 938-945

[10] Ogunniyi IO. Development of laboratory bench-top electric heating furnace. Unpublished Master's Degree Thesis, Metallurgical and Material Engineering Department, Federal University of Technology, Akure; 2003.

[11] Borode JO, Onyemeobi OO, Omotoyinbo JA. Suitability of some Nigerian clays as refractory raw materials. Journal of Engineering Management. 2000;1(2):14 - 18

[12] Okoli PN. Development and production of refractory crucibles from Nigerian kaolin. Journal of Engineering Technology and Industrial Applications 2000;1(2):12 -16.

[13] Folorunso DO, Olubambi PO, Borode JO. Characterization and qualitative analysis of some Nigerian clay deposits for refractory application. Journal of Applied Chemistry 2014;7(9):40-47.

[14] Manukaji JU. The effects of sawdust addition on the insulating characteristics of clays from the federal capital territory of Abuja. International Journal of Engineering Research and Applications 2013;3(2):6-9.

[15] Akinlabi O, Olanrewaju B, Akinola AO. Modeling dry compressive strength of sodium silicate bonded kaolin refractory bricks. Journals of Innovative Systems Design and Engineering 2013;4(3):13-19.

[16] Ijagbemi CO. Development and Performance Evaluation of Biomass Clay Lined Cook stove, Master Degree Thesis. Mechanical Engineering Department, Federal University of Technology, Akure; 2002

[17] Delta Steel Company Limited, Aladja. Physical and chemical properties of some Nigerian clays. National Steel Raw Materials Agency Delta, Zonal Office; 1984. 
[18] Sadik C, Albizane A, El Amrani I. Production of porous firebrick from mixing clay and recycled refractory waste with expanded perlite addition. Journal of Materials and Environmental Sciences 2013;4(6):981-986.

[19] Jo O, Philip AC. Performance evaluation of refractory bricks produced from locally sourced clay materials. Journal of Applied Science and Environmental Management 2014;18(2):151-157.

[20] Jock AA, Ayeni FA, Jongs LS, Kangpe NS. Development of refractory bricks from Nigerian Nafuta clay deposit. International journal of materials, methods and technologies 2013;1(10):189-195

[21] Nuhu AA, Abdullahi TA. Estimation of the effect of kaolin clay addition on the mechanical properties of foundry moulding sand bonded with grades 3 and 4 Nigerian gum Arabic (Acacia species). Middle-East Journal of Scientific Research 2008;3(3):126-133.

[22] Atanda P, Adeniyi O, Oluwole O. Development of heat treatment refractory bricks using local Nigerian clays. International Journal of Materials and Chemistry 2012;2(5): 185-191.

[23] Oke SR, Talabi HK, Olorunniwo OE, Atanda PO, Aramide FO. Production and characterization of clay bonded carbon refractory from Ifon clay and spent graphite electrode. International Journal of Metallurgical Engineering 2015;4(2):33-39.

[24] Olajide OI, Mchael OB, Terna TD. Production and characterization of aluminosilicate refractory brick using Unwana beach silica sand, Ekebedi and Unwana clays. British Journal of Applied Science and Technology 2015;5(5):461471.

[25] Abubakar I, Brinin Yauri UA, Faruq UZ, Noma SS, Sharif N. Characterization of Dabagi clay deposit for its ceramic potential. African Journal of Environmental Science and Technology 2014;8(8):455-459.

[26] Mathew GO, Owoeye SS. Characterization of Abaji clay deposits for refractory applications. Leonard Electronic Journal of Practices and Technologies. 2016;15(29):115-126.

[27] Aramide FO, Seidu SO. Production of refractory lining for diesel fired rotary furnace, from locally sourced kaolin and potter's clay. Journal of Minerals and Material Characterization and Engineering 2013;1:75-79

[28] Ndaliman MB. Some studies in refractory properties of termite hills in Nigeria. Nigeria Journal of Education and Techology 2001;2(1\&2):44-46.

[29] Babalola JB, Folorunso DO, Bodurin MO, Balogun OP. Property evaluation of Igbara-Odo clay for refractories. International Journal of Engineering and Technical Research 2014;2(1):79-82.

[30] Kipsanai JJ, Namango SS, Muumbo AM. A study of selected Kenyan anthill clays for the production of refractory materials. International Journal of Scientific and Research Publications 2017;7(9):169-179.

[31] Obiajunwa EI, Adebajo AC, Omobuwajo OR. Essential and trace element contents of some nigerian medicinal plants. Journal of Radioanalytical and Nuclear Chemistry 2002; 252(3):473-476

[32] Obiajunwa EI, Nwachwu JI. Simultaneous PIXE and PIGME analysis of a Nigerian tar sand sample from a deep borehole. Journal of Radioanalytical and Nuclear Chemistry 2000;245(3):659-661. 
[33] Obiajunwa EI. Analysis of some Nigerian solid minerals ores by energy dispersive X-ray fluorescence spectroscopy. Nuclear Instruments and Methods in Physics Research Section B: Beam Interactions with Materials and Atoms 2001;184(3):437440.

[34] Obiajunwa EI, Adebiyi FM, Omode PE. Determination of essential minerals and trace elements in Nigerian sesame seeds, using TXRF technique. Pakistan Journal of Nutrition. 2005;4(6):393-395

[35] Alhassan Y, Tsafe AI, Brinin-Yauri UA, Okunola OJ, Yargamji GI, Yebpella GG, Ndana M. EDXRF analysis of tantalite deposit of Mai-Kabanji, north-western Nigeria. Journal of Environmental Chemistry and Ecotoxicology 2010;2(7):117-119.

[36] Campbell JL, Babaluk JA, Cooper M, Grime GW, Halden NM. Strontium distribution in young-of-the-year Dolly Varden otoliths: Potential for stock discrimination. Nuclear Instruments and Methods in Physics Research Section B 2002;189(1-4):185189.

[37] Ugheoke BI, Onche EO, Namessan ON, Asikpo GA. Property optimization of kaolinrice husk insulating fire-bricks. Leonardo Electronic Journal of Practices and Technologies 2006;5(9):167-178.

[38] Chesters JH. Refractory production and properties. The Iron and Steel Institute. London;1973.

[39] Amkpa JA, Badarulzaman NA. Thermal conductivity of Barkin-Ladi fireclay bricks as refractory lining. IOSR Journal of Mechanical and Civil Engineering 2017;14(2):01-05

[40] ASTM. Standard methods for drying and fired shrinkages of ceramic whiteware clays. (Designation:C326). 2001;15:02

[41] Jock AA, Ayeni FA, Ahmed AS, Sullayman UA. Evaluation of the refractory properties of Nigerian Ozanagogo clay deposit. Journal of Minerals and Materials Characterization and Engineering 2013;1(6):321-325

[42] ASTM. Standard test method for pyrometric cone equivalent of fireclay and highalumina refractory material (CO8.02) 2018;15.01

[43] Aliyu S, Garba B, Danshehu BG, Isa AD. Studies on the chemical and physical characteristics of some selected clay samples. International Journal of Engineering Research and Technology 2013;2(7):171-183.

[44] Hassan MA, Yami AM, Raji A, Ngala MJ. Effects of sawdust and rice husk additives on properties of local refractory clay. The International Journal of Engineering and Science 2014;3(8):40-44.

[45] Sayel MF, Ghasi SA, Suleiman QA. Improvement of the refractoriness under load of fire-clay refractory bricks. Advanced Theoretical and Applied Mechanics 2012;5(4):161-172.

[46] Adejumo JA, Obioh IO, Ogunsola OJ, Akeredolu FA, Olaniyi HB. The atmospheric deposition of major and minor trace elements within and around cement factories. Journal of Radioanalytical and Nuclear. Chemistry 1994;179(2):195-204.

[47] Agboola JB, Abubakre OK. Investigation of appropriate refractory material for laboratory electric resistance furnace. Leonard Journal of Sciences 2009.8(14):235243. 